\title{
Seagrass selection by omnivorous and herbivorous consumers: determining factors
}

\author{
Patricia Prado ${ }^{1, *}$, Kenneth L. Heck Jr. ${ }^{2}$ \\ ${ }^{1}$ Institut de Recerca i Tecnología Agroalimentàries (IRTA), Aquatic Ecosystems, Ctra. Poble Nou km 5.5, \\ 43540 Sant Carles de la Ràpita, Tarragona, Spain \\ ${ }^{2}$ Dauphin Island Sea Lab. 101, Bienville Boulevard, Dauphin Island, 36528 Alabama, USA
}

\begin{abstract}
Consumers of seagrasses are increasingly recognized for their ability to shape landscape features and regulate energy flux in coastal ecosystems. To date, however, the nutritional characteristics and morphological features by which herbivores and omnivores make feeding decisions are poorly understood. To elucidate how consumers of marine vascular plants discriminate among different food resources, we conducted food-preference assays with seagrass leaves and seagrassincorporated agar diets of the 3 most common seagrass species of the Gulf of Mexico (Thalassia testudinum, Halodule wrightii and Syringodium filiforme). These 3 species were offered simultaneously to the most abundant local consumers: the omnivorous pinfish Lagodon rhomboides and filefish Stephanolepis hispidus, the herbivorous emerald parrotfish Nicholstina usta, and the herbivorous sea urchin Lytechinus variegatus. Consumption rates ( $\mathrm{g}$ fresh weight [FW]) of leaves or seagrass-incorporated agar diets were estimated over $24 \mathrm{~h}$ periods. Measured plant properties included $\mathrm{C}: \mathrm{N}, \mathrm{N}: \mathrm{P}$, total carbohydrates, protein and lipid concentrations, caloric content, percentage of organic matter, water and ash. Results showed that $S$. filiforme was preferred by all fish species $(81,60.2$ and $59 \%$ of total leaf consumption of pinfish, filefish and parrotfish, respectively), whereas sea urchins consumed the highest amounts of $H$. wrightii ( $71.2 \%$ of total). However, when leaf structure was removed, by incorporating ground leaf tissue into agar matrices, pinfish and filefish did not show any significant dietary preference. In contrast, parrotfish and sea urchins maintained their preferences for S. filiforme and $H$. wrightii, respectively. Parrotfish preference for $S$. filiforme coincided with highest lipid and carbohydrate contents, whereas the preference of sea urchins for $H$. wrightii could be explained by higher levels of the percentage of organic matter and caloric content. Our results suggest that structural plant features (e.g. leaf manipulability and/or visual recognition of resources) are the most important factors driving discrimination between seagrass species by omnivorous fish, whereas strict herbivores make feeding decisions that are highly influenced by nutritional characteristics, presumably as recognized by both olfaction and gustation.
\end{abstract}

KEY WORDS: Plant structure $\cdot$ Nutritional quality $\cdot$ Fish $\cdot$ Sea urchins $\cdot$ Feeding decision

\section{INTRODUCTION}

Foraging behaviors are an ensemble of complex feeding decisions aimed at optimizing the intake of energy and essential dietary elements within physical and chemical features of habitats (Stephens \& Krebs 1987). In marine organisms, foraging behaviors have been most often investigated from the perspective of predator species that seek scattered and often mobile prey of high nutritional value (Carr et al. 1996, Zimmer \& Butman 2000, Weissburg et al. 2002). In contrast, comparatively less information is available on how herbivores choose food resources, possibly because they are believed to face an apparent surplus of food and to be mainly influenced by qualitative plant characteristics. However, marine herbivores have major roles in controlling the structure and function of macrophyte communities (see reviews by Steneck \& 
Sala 2005, Valentine \& Duffy 2006), and understanding the feeding decision process remains a major challenge. In addition, we lack knowledge of the role of the often very abundant marine omnivores in structuring plant communities and whether their feeding decisions differ from those of herbivores.

Feeding decisions are intimately related to the sensory abilities of organisms (Dusenbery 1992) and might be variable across trophic levels due to requirements for detecting different types of food resources. For instance, many predators, including fish, are able to discriminate between living and dead prey, presumably because movement stimuli trigger attacks (e.g. Fernández-Diaz et al. 1994, Lima 2002). Vision appears to be crucial for the initial detection and orientation to prey and determining the optimum distance and angular deviation for the initiation of a rapid strike toward the prey (New 2002). In addition to movement, other visual cues such as shape, color and/or size also trigger predatory fish behavior (Parrish 1991, Liang et al. 1998) and may account for the development of camouflaging techniques or the acquisition of aposematic coloration by prey (Ang \& Newman 1998, Chiao \& Hanlon 2001). Predators also extract relevant spatial and temporal information about resource distribution from olfactory signals, particularly in the marine environment (Zimmer \& Butman 2000). Chemical attractants are believed to be primarily amino acids, although there also may be effects of quaternary ammonium bases, nucleotides and nucleosides, and organic acids released from animal flesh (Carr et al. 1996). However, diffusivity of chemicals in water is a slow process (on the order of $10^{-9} \mathrm{~m}^{2} \mathrm{~s}^{-1}$ ), and effects are most prevalent when there are large changes in concentration over short distances (Moore \& Crimaldi 2004). Therefore, chemosensory tracking may be particularly relevant in slow-moving invertebrates with reduced home ranges (e.g. whelks, sea stars and sea urchins), whose slow paces allow them more time to detect concentration profiles of chemical plumes (Weissburg et al. 2002). In marine vertebrates, food items are finally evaluated by taste buds in the oral and pharyngeal cavities, lips, esophagus and gills, as well as by specialized barbels (Kasumyan \& Døving 2003). The sense of touch can detect the presence of acute outgrowths and spines and also provides supplementary information in the process of prey discrimination (see review by Kasumyan \& Døving 2003).

Herbivores substantially differ from predatory/ omnivorous taxa, in having to deal with a widely dispersed mosaic of food resources of varying nutritional quality (Senft et al. 1987). Thus, they exploit resources that fundamentally differ from mobile prey by being attached to the substrate and, usually, less nutritious than animals. In some cases, such as those of herbi- vorous mollusks, the association with plants is so highly evolved that they have developed specialized feeding apparati that are specific for the size and toughness of targeted plants (Steneck \& Watling 1982). Yet, there is little evidence that feeding decisions of macroherbivores such as fish and sea urchins are based on the structural and/or color features of plants (but see Goecker et al. 2005, Prado et al. 2010). These consumers possess distinctive types of buccal apparati such as the Aristotle's lantern of sea urchins or the jaws of fishes (see Watts et al. 2001), and may respond to structural aspects of food items such as shape, size, toughness and manipulability of food (Klinger 1982). In contrast, since seagrass consumers often dwell in highly oligotrophic areas and regions, the mechanisms underlying their food selection have been mostly explained by qualitative changes in food resources and the capacity of grazers to control the excess primary production following nutrient enrichment (e.g. Heck et al. 2000, 2006, Valentine \& Heck 2001). Nutrient-poor diets, however, may also enhance consumption rates through compensatory feeding responses to circumvent the effects of low nutritional quality (Cruz-Rivera \& Hay 2000). In particular, seagrasses often have elevated C:N ratios, due to high levels of structural carbohydrates (lignin and cellulose) that cannot be easily digested by most marine organisms (e.g. Klumpp \& Nichols 1983) and might influence preference and/or ingestion rates by consumers. Other factors such as caloric content, amount of organic matter, total protein and total lipid content may also be detected by grazers and result in enhanced consumption rates of higher quality plants (Montgomery \& Gerking 1980, Targett \& Targett 1990). Additionally, an array of marine plants is chemically defended and avoided by consumers (reviewed by Hay \& Fenical 1988), thus providing indirect evidence that herbivores also detect chemical metabolites, presumably through olfaction and gustation.

The objectives of the present study were 2-fold. First, we compared the relative importance of nutritional characteristics versus morphological features in the selection of seagrass resources by the most abundant omnivore and specialist marine herbivores in the northern Gulf of Mexico (the omnivorous pinfish Lagodon rhomboides and filefish Stephanolepis hispidus, the herbivorous parrotfish Nicholstina usta, and the sea urchin Lytechinus variegatus). Second, we assessed the consistency of these dietary preferences between the 2 taxon types of seagrass macrograzers (fish and sea urchins), which may have distinctive sensory abilities and/or nutritional requirements. We used the 3 most common seagrass species in the northern Gulf of Mexico (i.e. Thalassia testudinum, Halodule wrightii and Syringodium filiforme) and assessed the relative importance of their nutritional features and leaf tough- 
ness as we offered them to the 4 consumer species in the form of whole leaves and seagrassincorporated agar diets.

\section{MATERIALS AND METHODS}

Stomach content analyses. The relative importance of seagrass leaves in the diet of pinfish Lagodon rhomboides $(\mathrm{n}=13)$, parrotfish Nicholsina usta $(\mathrm{n}=14)$ and filefish Stephanolipis hispidus $(\mathrm{n}=23)$ was first investigated by stomach content analysis of individuals collected in previous seagrass surveys along the northern Gulf of Mexico (Fodrie et al. 2010). Since assessing the amount of particulate seagrass matter was the main objective of the stomach analyses, an indirect volumetric estimation was adopted (see review by Hyslop 1980), and the items were expressed as the frequency of occurrence $(\% \mathrm{O})$. In addition, dietary items and the volume of material versus the total volume of stomach contents were estimated under a microscope.

Analyses of stomach contents were also conducted for the sea urchin Lytechinus variegatus ( $\mathrm{n}=10$ ) collected at the same site as individuals used in experimental trials (see below). These analyses revealed seagrass as the main dietary item.

Collection of plant samples and consumers. Shoots of Thalassia testudinum, Halodule wrightii and Syringodium filiforme were harvested haphazardly from a mixed seagrass bed in St. Joseph Bay, Florida, USA (northeastern Gulf of Mexico, 30'N, 85.5'W) in November 2008. We selected this meadow because it is located within a state park and has low anthropogenic input (Heck \& Valentine 1995), so factors affecting feeding decisions could be attributed confidently to differences in the natural characteristics of seagrass resources. Care was taken to collect shoots with intact vertical rhizomes to minimize chemical changes occurring over time in detached plants. Fish (Lagodon rhomboides, Nicholsina usta and Stephonolipis hispidus) and sea urchins (Lytechinus variegatus) were collected in both November 2008 (simultaneously with the seagrass samples) and then again in October 2009 for food-preference experiments with seagrass-infused agar diets. Sea urchins were collected by snorkeling within the seagrass bed where shoots were collected, and were approximately $4 \mathrm{~cm}$ in diameter. Fish were collected using a $5 \mathrm{~m}$ otter trawl $(2.0 \mathrm{~cm}$ body mesh, $0.6 \mathrm{~cm}$ bag mesh, $0.3 \times 0.7 \mathrm{~m}$ doors). Trawls consisted of 2 min tows behind small $(<7 \mathrm{~m})$ research vessels traveling at approximately 2.5 knots over local seagrass meadows (mainly T. testudinum), along with scattered unvegetated patches, at depths of from 0.5 to $1.5 \mathrm{~m}$. Individuals of sizes that previously had seagrass fragments within their stomachs (i.e. $20 \mathrm{~cm}$ pinfish,
$16 \mathrm{~cm}$ parrotfish and $11 \mathrm{~cm}$ filefish) were selected, and the remaining fish were released. Fish, sea urchins and plants were kept in separate aerated coolers with seawater and transported to the laboratory for further sorting and experimental trials.

Laboratory manipulations. Once in the laboratory, seagrass samples of each species were divided into two; one half was immediately frozen at $-18^{\circ} \mathrm{C}$ and the other half was placed alive in a 7501 tank with aeration. Fish species and sea urchins (18 individuals each) were kept in different tanks (750 l and 125 l, depending on availability) and allowed to acclimate to laboratory conditions for $24 \mathrm{~h}$ with no food prior to each feeding trial. Experiments were conducted on consecutive days for each consumer species due to time and space restrictions. Filefish, the first species tested, were not fed before trials, whereas frozen algae were used to feed parrotfish and sea urchins until $24 \mathrm{~h}$ prior to the start of the experiment. In the case of pinfish, individuals were kept alive within 3 large mesh net cages (ca. $1 \mathrm{~m}^{2}$ ) in an area of the sea with sandy bottom, near the laboratory at Dauphin Island, and fed on frozen shrimp and algae.

Every day after collection, seagrass shoots of each species were cleansed of epiphytes by gently scraping with a razor blade, their tips were cut to remove previous bite marks, and they were blot-dried carefully. Then, $\sim 0.7$ to $1 \mathrm{~g}$ of each species was weighed on an electronic balance (0.001 $\mathrm{g}$ accuracy) and labeled for use as replicate units in feeding trials. Four groups of 3 seagrass ramets - each including a haphazard combination of each seagrass species attached to a picket with garden twist tie-were placed into experimental tanks with a $125 \mathrm{l}$ water capacity $(\mathrm{n}=6)$. In each tank, we added 3 individuals of the sea urchin Lytechinus variegatus, each separated by a mesh net, and we offered them a simultaneous combination of the 3 seagrass species (i.e. 1 picket with the 3 seagrass ramets, 1 of each species). The fourth group of 3 seagrass ramets - also separated from grazers by a mesh netwas used as a tank control to check for autogenic changes over the $24 \mathrm{~h}$ period. This procedure was conducted for the 3 other consumer species. In all cases, feeding trials were conducted over a $24 \mathrm{~h}$ period (usually, 09:00 to 09:00 h). After $24 \mathrm{~h}$, the remaining plants were removed from each tank, blot-dried, weighed and the numbers of bite marks counted. Results were expressed as the number of bite marks per ramet and the biomass loss per individual per day. Results showed no significant autogenic changes in seagrass during control tests conducted with the 4 consumer species $\left(t_{\text {Hal }}=1.12, \mathrm{df}=23, \mathrm{p}>0.05 ; t_{\text {Thal }}=-0.45, \mathrm{df}=\right.$ $\left.23, \mathrm{p}>0.05 ; t_{\mathrm{Syr}}=-1.71, \mathrm{df}=23, \mathrm{p}>0.05\right)$.

Nutritional analyses. Nutrient contents of consumers' tissues were investigated to assess possible 
differences in molar ratios $(\mathrm{C}: \mathrm{N}, \mathrm{C}: \mathrm{P}$ and $\mathrm{N}: \mathrm{P})$ related to trophic level (omnivorous vs. herbivorous fish) and taxonomic group (fish vs. sea urchins). Stomach contents of each fish species ( $\mathrm{n}=6$ for each species) were totally removed, carcasses dried at $70^{\circ} \mathrm{C}$ for several days ( 2 to $5 \mathrm{~d}$ depending on body size) until reaching constant weight, and then the whole body was ground to a powder in a grinding mill. For sea urchins $(n=6)$, the whole, clean body excluding calcified structures (i.e. test, lantern and spines) was dried at $70^{\circ} \mathrm{C}$ for $48 \mathrm{~h}$ and then ground to a powder with a mortar and pestle. All individuals were analyzed in duplicate for $\mathrm{C}$ and $\mathrm{N}$ content using a Costech ECS410 CHN analyzer. Phosphorus content was determined through dry oxidation and acid hydrolysis extraction followed by a colorimetric analysis. Elemental ratios (C:N, N:P and C:P) were calculated on a mole:mole basis.

For each seagrass species, nutritional variables (except protein contents; see below) were examined on 6 replicate samples, each consisting of 1 shoot for Thalassia testudinum and 2 and 6 pooled shoots for Syringodium filiforme and Halodule wrightii, respectively, to facilitate grinding and ensure enough biomass for the analyses. Seagrass leaves (free of visible epiphytes) were separated according to species, dried to a constant weight at $70^{\circ} \mathrm{C}$, ground to a fine powder with a mortar and pestle, and then analyzed in duplicate for $\mathrm{C}, \mathrm{N}$ and $\mathrm{P}$ content.

Water content within seagrass leaves was measured as the weight difference between fresh and dried material. Total organic matter (\%) was calculated by subtraction after combustion of dry samples at $500^{\circ} \mathrm{C}$ for $5 \mathrm{~h}$ and obtaining the ash-free dry weight.

For calorimetry, dried leaf material was ground and pelletized. The pellets were then dried to constant weight before burning in the Parr 6725 Semimicro calorimeter. Samples were run after appropriate calibration of the calorimeter. Pellets were mixed with benzoic acid to ensure complete combustion and then subjected to appropriate corrections. Gross energy values (heat of combustion) were expressed in calories per gram dry weight (DW) per liter.

Total lipids (\%) were extracted from dried seagrass samples by direct elution with chloroform and methanol, using the methods described by Folch et al. (1957). Total carbohydrates (\%) in seagrass species were determined with the widely used phenol-sulfuric acid assay of Dubois et al. (1956) based on colorimetric absorbance at $490 \mathrm{~nm}$.

Total protein analyses were carried out by combustion at the Eurofins Scientific Inc. facility in Des Moines, IA. One sample, consisting of pooled dried leaf material from previous analyses, was analyzed per seagrass species.

Measurement of plant toughness. The physical resistance of seagrass leaves was assessed with a pen- etrometer as described by Duffy \& Hay (1991). Briefly, leaves were clamped below the pin of the penetrometer, and sand was added to a plastic cup attached to the device, until the leaf tissue was completely pierced. Sand weights were transformed into force values and expressed in kilograms per meter per second.

Agar diets. Agar diets were used to test the capacity of consumers to detect differences in plant structural features that, in turn, might exert a controlling effect on food preferences. Since marine organisms have very little enzymatic activity for insoluble carbohydrates (Farmanfarmaian \& Phillips 1962, Ojeda \& Caceres 1995), reconstituted agar diets offer an appropriate substrate for comparative purposes with natural food items. Diets were prepared from the frozen seagrass material collected in St. Joseph Bay in November 2008. Epiphytes were removed from the seagrass and leaves were dried at $70^{\circ} \mathrm{C}$ for $24 \mathrm{~h}$ and then ground to a fine powder. Four grams of each seagrass species were placed in a heated mixture of $100 \mathrm{ml}$ of distilled water (as indicated by Goecker et al. 2005) and $2 \mathrm{~g}$ of agar (Carolina Biological Supply). The mixture was poured into small molds ( $2 \mathrm{~cm}$ diameter) and allowed to cool for $1 \mathrm{~h}$ within a refrigerator. Samples were then removed from the molds, weighed to the nearest $0.001 \mathrm{~g}$ and labeled by piercing them with a wire attached to a small tag. For each consumer species, the experimental design was conducted as for the fresh seagrass leave trials. Autogenic controls conducted simultaneously with food-preference trials for each of the 4 consumers indicated a significant decline in diet weight $\left(t_{\mathrm{Hal}}=31.87, \mathrm{df}=23, \mathrm{p}<0.001 ; t_{\text {Thal }}=41.62, \mathrm{df}=\right.$ $23, \mathrm{p}<0.001 ; t_{\mathrm{Syr}}=41.66, \mathrm{df}=23, \mathrm{p}<0.001$ ) over a $24 \mathrm{~h}$ period (ca. $6 \%$ of initial weight). Hence, the amount of reconstituted diets consumed was estimated by adding biomass loss from autogenic controls from bitten agar block units. The experimental trials took place in October 2009 and, as described for leaf preferences, were conducted during consecutive days for each consumer.

Data analyses. The experimental design consisted of 6 tanks, each containing 3 independent consumers and approximately equal amounts of 3 simultaneous diets over a $24 \mathrm{~h}$ period. The Friedman ANOVA by ranks (Conover 1980) and Kendall's concordance coefficient (Kendall 1955) were used to assess significant differences in consumption rates among diets and the degree of agreement among the rankings of each consumer (see Danell et al. 1994, Cronin et al. 2002 for similar approaches). Seagrass and reconstituted tissues consistently showed consumer marks on at least one of the 3 offered species; therefore, all replicates were included in the analyses. For each consumer, the entire set of observed consumption values ( $g$ wet weight [WW]) was ranked from the smallest to the 
largest (Conover \& Iman 1981). Then, non-parametric post hoc comparisons (Wilcoxon matched pairs test) were used to assess significant differences between diets.

Nutritional variables (nutrient ratios, energy content, and percentages of water content, organic matter, lipids and carbohydrates) and leaf toughness were investigated with 1-way ANOVA and StudentNewman-Keuls post hoc analyses. Data were transformed when necessary to meet ANOVA assumptions of normality (Chi-squared test) and homogeneity of variances (Cochran's test). All statistical analyses were performed using Statistica software.

\section{RESULTS}

\section{Stomach contents}

Seagrass leaves and leaf detritus were the main dietary items of parrotfish Nicholstina usta (80 to 100\% of stomach contents; see Table 1). However, due to difficulties in identifying partly digested leaf fragments, it was not possible to determine which seagrass species were present within the stomachs. Seagrasses were a frequent item in pinfish Lagodon rhomboides of ca. $20 \mathrm{~cm}$ size $(\sim 3 \%)$, as well as in filefish Stephanolepis hispidus $>10 \mathrm{~cm}$ (an average of $6 \%$ ).

Table 1. Frequency of occurrence (\%) of all dietary items, and indirect volumetric estimation of the seagrass amount ingested by each of the 4 consumer species investigated. For further details see the 'Materials and methods' section

\begin{tabular}{|lcc|}
\hline $\begin{array}{l}\text { Consumer } \\
\text { Dietary item }\end{array}$ & $\begin{array}{c}\text { Frequency of } \\
\text { occurrence (\%) }\end{array}$ & $\begin{array}{c}\text { Seagrass gut } \\
\text { content (\%) }\end{array}$ \\
\hline $\begin{array}{l}\text { Pinfish Lagodon rhomboides } \\
\text { Amphipods }\end{array}$ & 41.6 & \\
Detritus & 83.33 & \\
Seagrass leaves & 58.33 & 3 \\
Filefish Stephanolepis hispidus & & \\
Amphipods & 52.17 & \\
Bivalves & 47.82 & \\
Bryozoans & 13.04 & \\
Decapods & 56.52 & \\
Isopods & 21.73 & \\
Gastropods & 4.34 & \\
Algae & 13.04 & \\
Detritus & 73.91 & \\
Seagrass leaves & 69.56 & \\
Parrotfish Nicholstina usta & & \\
Detritus & 35.7 & \\
Seagrass leaves & 100 & 87 \\
Sea urchins Lytechinus variegatus & \\
Decaying leaves & 100 & \\
Seagrass leaves & 100 & \\
& & \\
& & \\
& & \\
\end{tabular}

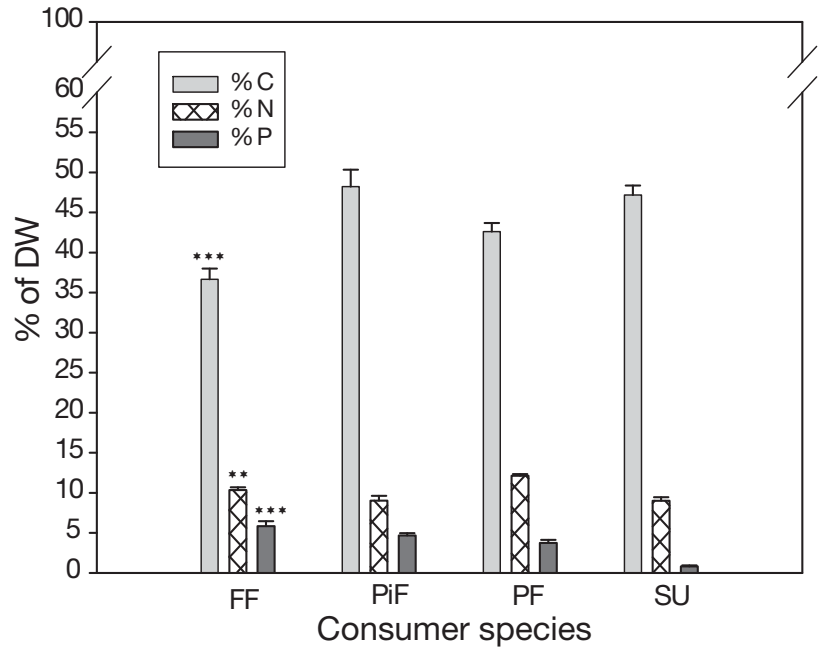

Fig. 1. Nutrient contents (percent dry weight [DW]) in the 4 consumer species investigated. Significant results (1-way ANOVA $\left._{i}{ }^{* *} \mathrm{p}<0.01,{ }^{* * *} \mathrm{p}<0.001\right)$ are indicated. Cochran's $C$ was not significant. FF: file fish; PiF: pinfish; PF: parrot fish; SU: sea urchin

\section{Nutrient contents in consumers}

There were important differences in $\% \mathrm{C}, \% \mathrm{~N}$ and $\% \mathrm{P}$ contents among consumers (Fig. 1). In particular, sea urchins Lytechinus variegatus showed very low $\mathrm{P}$ content $(0.8 \pm 0.13 \% \mathrm{P})$, ca. 7.2 to 4.6 times lower than fish. Among the fish species, parrotfish displayed the lowest P content $(3.7 \pm 0.4 \% \mathrm{P})$, and they compared well with omnivorous fish $(5.8 \pm 0.62$ and $4.6 \pm 0.3 \% \mathrm{P}$ in filefish and pinfish, respectively). Despite significant differences in $\% \mathrm{~N}(8.9 \pm 0.4,12.1 \pm 0.2,10.3 \pm 0.3$ and $9 \pm 0.6 \% \mathrm{~N}$ in sea urchins, parrotfish, filefish and pinfish, respectively) and \%C (47.1 $\pm 1.1,42.6 \pm 1,36.6 \pm$ 1.3 and $48.2 \pm 2.1 \% \mathrm{~N}$ in sea urchins, parrotfish, filefish and pinfish, respectively), there were no obvious patterns that could be associated with dietary habits or taxonomic group.

\section{Leaf-preference assays}

Results of Friedman's test showed significant effects of seagrass species on consumption rates for all 4 consumers (see Table 2). Kendall's coefficient of concordance also showed a considerable level of agreement within consumer species, particularly for parrotfish (Table 2). Fish showed highest preference for Syringodium filiforme, intermediate for Halodule wrightii and lowest for Thalassia testudinum (see Fig. 2). In contrast, $H$. wrightii was the first choice of sea urchins, followed by $S$. filiforme and $T$. testudinum (Fig. 2). 
Table 2. Friedman's ANOVA $\chi^{2}$ and Kendall's coefficient of concordance $(W)$ for ranked consumption rates on seagrass leaves. In Wilcoxon matched pairs (WMP) post hoc comparisons, significantly different consumption rates between pairs of seagrasses are indicated: ${ }^{* *} p<0.01,{ }^{* * *} p<0.001$. Thal: Thalassia testudinum, Hal: Halodule wrightii; Syr: Syringodium filiforme

\begin{tabular}{|ccc|}
\hline $\begin{array}{l}\text { Consumer } \\
(\mathrm{n}=18, \mathrm{df}=2)\end{array}$ & $\begin{array}{c}\text { Friedman's } \\
\text { ANOVA } \chi^{2}\end{array}$ & Kendall's $W$ \\
\hline Pinfish & 18.66 & $0.524^{* *}$ \\
WMP post hoc: & Thal $=\mathrm{Hal}<\mathrm{Syr}$ & \\
Filefish & 22.11 & $0.614^{* * *}$ \\
WMP post hoc: & Thal $<\mathrm{Hal} \leq \mathrm{Syr}$ & \\
Parrotfish & 32.44 & $0.901^{* * *}$ \\
WMP post hoc: & Thal $<\mathrm{Hal}<\mathrm{Syr}$ & \\
Sea urchin & 18.75 & $0.521^{* * *}$ \\
WMP post hoc: & Thal $<$ Syr $<$ Hal & \\
& \\
\hline
\end{tabular}

\section{Nutritional characteristics of seagrasses}

All the nutritional features investigated displayed significant differences among seagrass species (Fig. 3). Syringodium filiforme had the highest \% $\mathrm{N}$, lipid and carbohydrate contents, as well as the lowest \% C. Thalassia testudinum displayed the lowest levels of total carbohydrates and lipids, whereas all other variables investigated showed intermediate amounts. Halodule wrightii displayed the lowest $\% \mathrm{~N}, \% \mathrm{P}$ and water content, whereas \% $\%$, \% $\mathrm{OM}$ and energy content were highest.

\section{Leaf toughness}

There were significant differences in leaf toughness among investigated seagrass species ( $\mathrm{df}=2, F=$ 127.23, $\mathrm{p}<0.001$ ). The force required to pierce individual seagrass leaves with the penetrometer was highest in Syringodium filiformis $(1.99 \pm 0.15 \mathrm{~N})$, followed by Thalassia testudinum $(1.17 \pm 0.07 \mathrm{~N})$ and lowest in Halodule wrightii $(0.17 \pm 0.03 \mathrm{~N})$, thus coinciding with differences in leaf thickness.

\section{Agar-preference assays}

Friedman's tests showed significant effects of reconstituted seagrass species on consumption rates for parrotfish and sea urchins, but not for pinfish and filefish (see Table 3), and Kendall's coefficient displayed good agreement among individual herbivores, but not among omnivores. Non-parametric post hoc comparisons (Wilcoxon matched pairs test) showed that par- rotfish and sea urchins maintained the same order of preferences as in previous leaf assays (see Fig. 4).

\section{DISCUSSION}

Plant features influencing consumer preferences were markedly different between omnivore and herbivore species. Omnivorous fish, Lagodon rhomboides

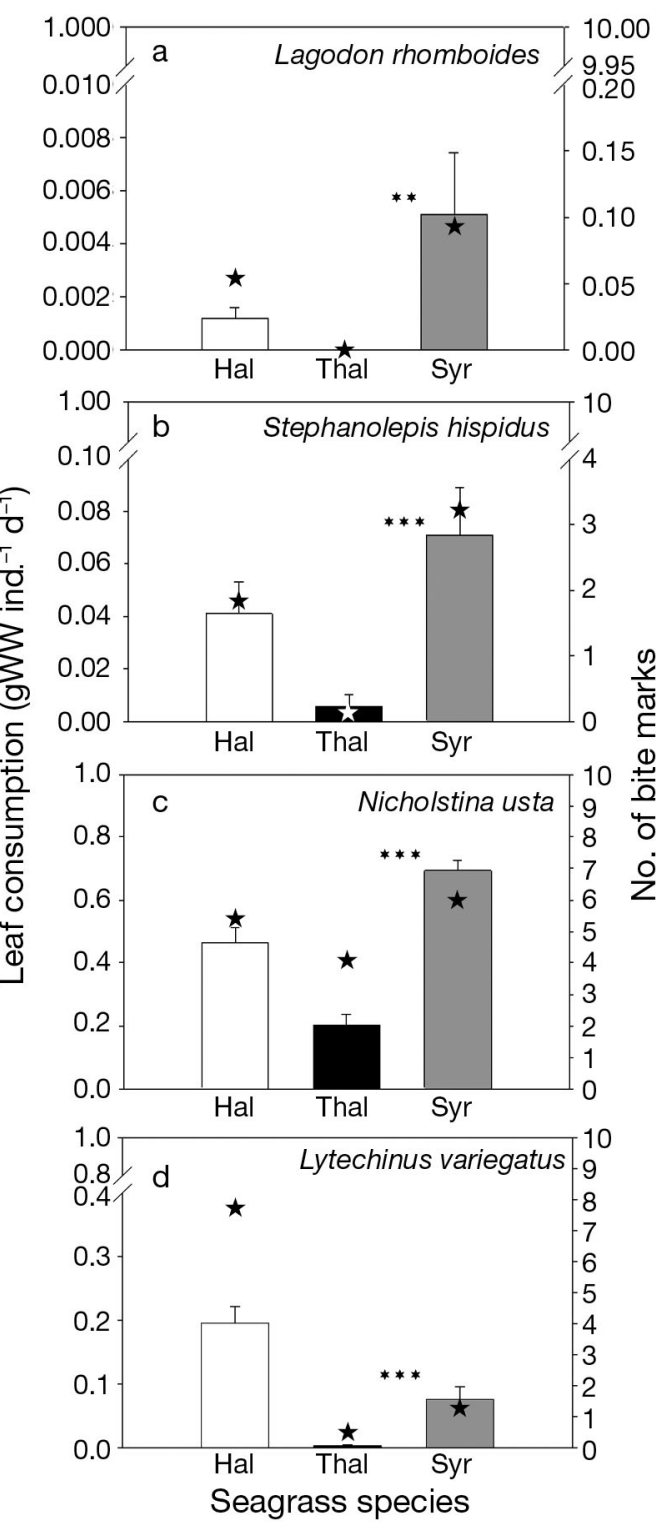

Fig. 2. Consumption rates of leaf material (g wet weight [WW] ind. ${ }^{-1} \mathrm{~d}^{-1}$; mean $\pm \mathrm{SE}$ ) of the 3 seagrass species (Hal: Halodule wrightii; Thal: Thalassia testudinum; Syr: Syringodium filiforme) presented to each of the 4 consumer species investigated (bars; left axis); and mean number of bite marks observed on the offered material (star symbols; right axis). ${ }^{* *} \mathrm{p}<0.01,{ }^{* * *} \mathrm{p}<0.001$ 
Table 3. Friedman's ANOVA $\chi^{2}$ and Kendall's coefficient of concordance $(W)$ for ranked consumption rates on reconstituted seagrass tissues. In Wilcoxon matched pairs (WMP) post hoc comparisons, significantly different consumption rates between pairs of seagrasses are indicated: ${ }^{* *} \mathrm{p}<0.01$, ${ }^{* * *} \mathrm{p}<0.001$. Thal: Thalassia testudinum; Hal: Halodule wrightii; Syr: Syringodium filiforme

\begin{tabular}{|lcc|}
\hline $\begin{array}{l}\text { Consumer } \\
(\mathrm{n}=18, \mathrm{df}=2)\end{array}$ & $\begin{array}{c}\text { Friedman's } \\
\text { ANOVA } \chi^{2}\end{array}$ & Kendall's $W$ \\
\hline $\begin{array}{l}\text { Pinfish } \\
\text { WMP post hoc: }\end{array}$ & 3.36 & 0.093 \\
$\begin{array}{l}\text { Filefish } \\
\text { WMP post hoc: }\end{array}$ & 1.50 & 0.041 \\
$\begin{array}{l}\text { Parrotfish } \\
\text { WMP post hoc: }\end{array}$ & $\begin{array}{c}24.33 \\
\text { Thal }=\mathrm{Hal}<\mathrm{Syr} \\
\text { Sea urchin } \\
\text { WMP post hoc: }\end{array}$ & $\begin{array}{c}17.77 \\
\text { Thal }=\mathrm{Syr}<\mathrm{Hal}\end{array}$ \\
\hline
\end{tabular}
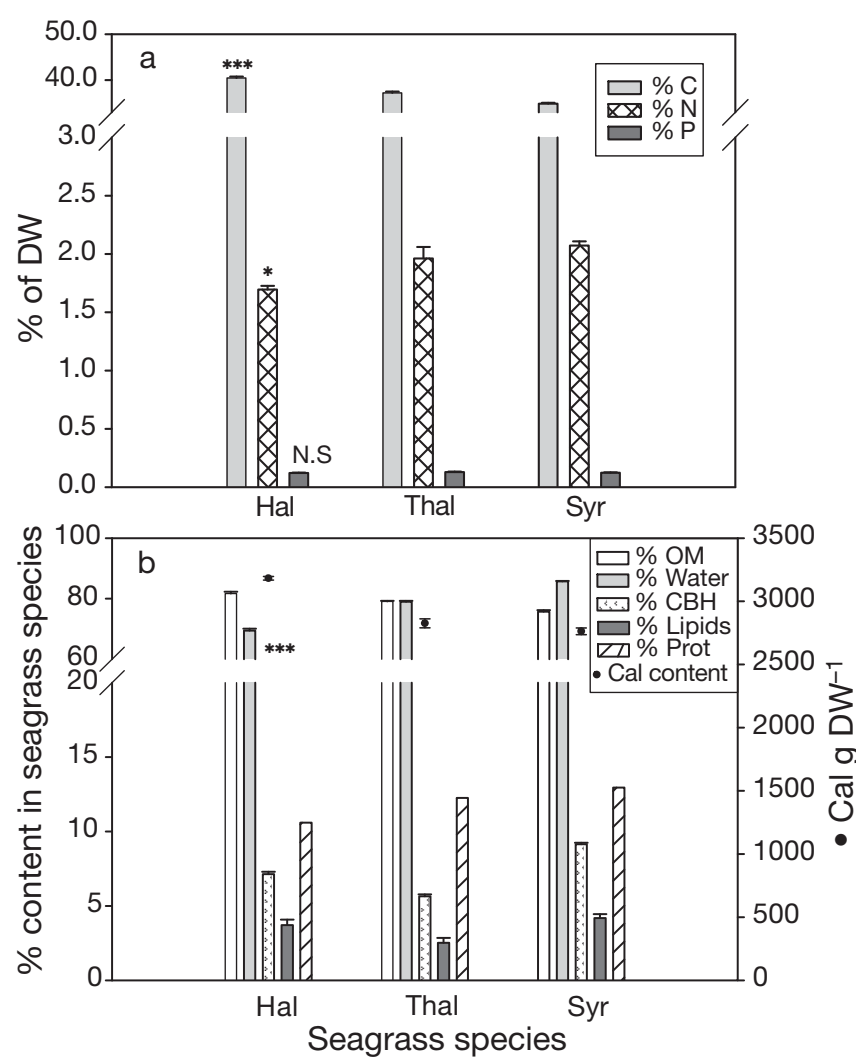

Fig. 3. (a) Nutrient contents (percent dry weight [DW] $\left({ }^{*} p<\right.$ $0.05,{ }^{* * *} p<0.001$; NS: not significant) and (b) nutritional characteristics of the 3 seagrass species (Hal: Halodule wrightii; Thal: Thalassia testudinum; Syr: Syringodium filiforme) used in food-preference assays. Percent water is based on wet mass, while other percentages indicated are based on dry mass. Significant results are indicated (1-way ANOVA; ${ }^{* * *} p<0.001$ for all variables except percent protein content for which only 1 replicate sample was analyzed). Cochran's $C$ was not significant for most variables, except for water, organic matter (OM) and energy content (for further details see the 'Materials and methods-Data analyses' section). $\mathrm{CBH}$ : carbohydrates; Prot: protein; Cal: calorie and Stephanolepis hispidus, were able to discriminate among seagrass species when plant structure was preserved, but not when food was offered in the form of agar diets. In contrast, preferences of the parrotfish Nicholstina usta and the sea urchin Lytechinus variegatus were not altered by the loss of plant structure, and they consistently consumed higher amounts of

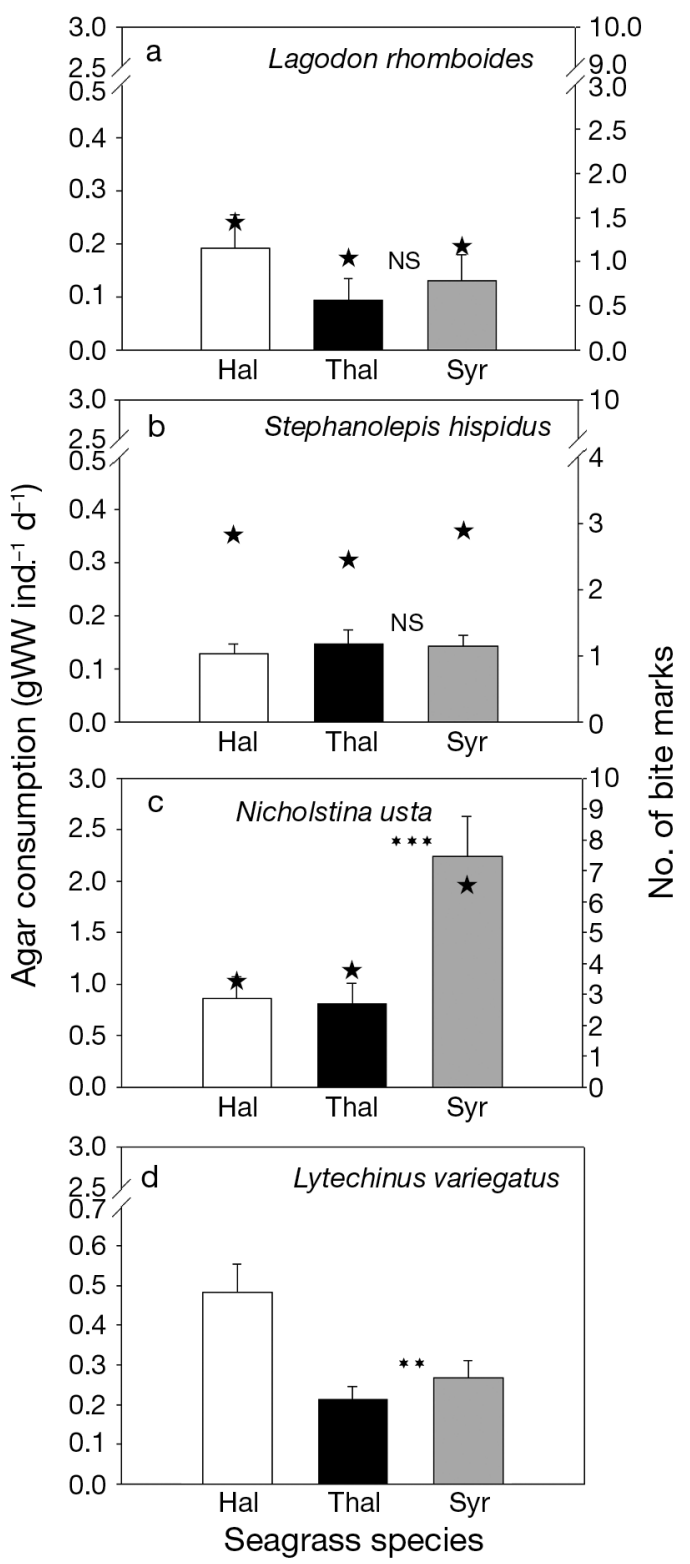

Fig. 4. Consumption rates of agar material ( $g$ wet weight [WW] ind.-1 $\mathrm{d}^{-1}$; mean $\pm \mathrm{SE}$ ) made of dried seagrass leaves (Hal: Halodule wrightii; Thal: Thalassia testudinum; Syr: Syringodium filiforme) and presented to the 4 consumer species investigated (bars; left axis). Mean number of bite marks observed on the offered material (star symbols; right axis). For sea urchins, continuous grazing on agar blocks prevented the identification of individual marks (values not shown). ${ }^{* *} \mathrm{p}<0.01,{ }^{* * *} \mathrm{p}<0.001$; NS: not significant 
seagrass material (leaves and agar diets) than omnivore fish. Although the generality of our conclusions is constrained by the relatively low number of common consumer species in the system, our results suggest that nutritional differences among seagrass resources are not a driving force in the selection of seagrass species by omnivorous fish. In contrast, nutritional characteristics appear to play a major role in the ability of herbivorous parrotfish and sea urchins to detect seagrass resources, even when variations in nutritional composition are very low.

Omnivorous species seek food resources with a very wide range of nutritional characteristics, shape, texture and mobility (Liang et al. 1998, Zimmer \& Butman 2000, New 2002). Our results show, however, that nutritional characteristics are not the main mechanisms driving plant selection by the 2 investigated omnivorous fish. Nutrient additions have been shown to enhance consumption of vegetal resources by pinfish (Heck et al. 2000, 2006), but nutritional differences between offered seagrasses were small (ca. $0.3 \%$ of N), and may not be enough to drive consumption patterns of omnivorous species under natural, non-nutrient-enriched conditions. Cronin et al. (2002) found that selective feeding on freshwater weeds and algae by omnivorous crayfish was influenced by both tissue structure and nutritional traits, but qualitative differences among investigated macrophytes were also greater. In contrast, we found that structural plant variables-most likely those related to plant shape and size and/or food manipulability - may play a central role in the food selection process of omnivorous pinfish and filefish. There is experimental evidence that vision is crucial for the initial detection of living prey by fish (New 2002), and food choice is often associated with prey shape and size characteristics, regardless of the taxonomic identity of the prey (Checkley 1982, Hambright 1991). In fact, the relationship between buccal apparatus and diet has previously been indicated as an important factor driving the type of plant selected and the feeding performance of grazers (e.g. Steneck \& Watling 1982, Jensen 1997). The narrower leaves of Halodule wrightii and Syringodium filiforme may be easier to manipulate than the wide leaves of Thalassia testudinum, particularly for fish with fused teeth, such as filefish. For instance, Klinger (1982) showed that variation in diet shape strongly influenced consumption of Lytechinus variegatus and that cubic-shaped morphologies registered the highest rates. Equally, for the mouth shapes and individual size ranges examined, natural seagrass leaves might be, comparatively, more difficult to manipulate than reconstituted diets. This could partly explain the enhanced consumption rates (g WW) observed for all investigated species (Figs. 2
\& 4), despite the low capacity of organisms to digest agar (Farmanfarmaian \& Phillips 1962, Ojeda \& Cáceres 1995), although the undergoing of compensatory feeding mechanisms cannot be excluded (Cruz-Rivera \& Hay 2000). In contrast, food toughness may be important for small invertebrate grazers such as amphipods (Taylor et al. 2002), but it does not seem to explain the observed patterns of macrograzers, possibly because plants' physical resistance to being bitten is much lower than the force that can be exerted by fish (and sea urchins) jaws.

Conversely to omnivores, the studied herbivore species first selected plants based on their nutritional characteristics, whereas structural features were only involved in latter discrimination between lesspreferred items (see also Vergés et al. 2007, Prado et al. 2010 for structural plant effects). In macrograzers, such as fish and sea urchins, some studies have already highlighted the role of nutritional characteristics due to physiological constraints and/or the presence of toxins in food preferences and consumption rates (e.g. Lobel \& Ogden 1981, Paul \& Hay 1986, Goecker et al. 2005). The role of secondary metabolites has been indicated for many species of macroalgae (Paul \& Hay 1986, Hay \& Fenical 1988), but, despite their widespread occurrence in seagrasses (McMillan 1984), they do not seem to cause the avoidance of Thalassia testudinum and Halodule wrightii by macrograzers such as Lytechinus variegatus (Steele \& Valentine 2010). In contrast, other herbivores such as amphipods have been shown to have a great capacity for discriminating among plant resources based on qualitative contents of chemical deterrents (Duffy \& Hay 1994, Taylor et al. 2003). The herbivorous amphipod Ampithoe longimana appears to discriminate among specific tissues of Sargassum flipidendula based on both structural and compositional characteristics; thus, older regions of the thallus are constitutively defended against grazing through enhanced toughness, and meristematic regions, by higher levels of chemical defenses (Taylor et al. 2002). Yet, our results for herbivorous parrotfish suggest that enhanced consumption of Syringodium filiforme and depressed consumption of $T$. testudinum could be explained by the levels of lipid and carbohydrates in seagrass species (Table 3: see also Montgomery \& Gerking 1980). Preference for Syringodium spp. over Thalassia spp. is consistent with previous field observations of selective seagrass grazing by reefassociated urchins and parrotfishes (Tribble 1981). Armitage \& Fourqurean (2006) also found consistently higher parrotfish grazing rates on $H$. wrightii compared to T. testudinum (ca. 25 and $65 \%$ of daily gross leaf production) even after nutrient additions. However, our results differ from those of Lobel \& Ogden 
(1981) for the bucktooth parrotfish Sparisoma radians, which displayed higher preference for $H$. wrigthii and $T$. testudinum than for $S$. filiforme.

In contrast, sea urchins primarily preferred Halodule wrightii during both whole-plant and agar experiments, suggesting that nutritional characteristics driving plant consumption may vary among species or taxa, according to their physiological requirements. Unfortunately, our results suggest that nutritional seagrass aspects determine dietary preferences of sea urchins, but are inconclusive about the factors causing it. None of the investigated variables alone could fully explain the consumption patterns of Lytechinus variegatus, suggesting that several qualitative factors must be involved simultaneously (e.g. H. wrightii may provide a high organic matter and energy-rich diet, which might be supplemented with enhanced carbohydrates and lipids from Syringodium filiforme). Beddingfield \& McClintock (1998) did not observe a significant preference for any plant species during laboratory experiments when sea urchins were fed with protein and lipid-rich Thalassia testudinum compared to $S$. filiforme. Nutritional characteristics, however, may be subjected to greater variation among locations than among seagrass species within a location, thus contributing to patchiness in herbivory patterns. For instance, T. testudinum from Perdido Bay (Florida, northern Gulf of Mexico), had nearly 2 times more lipids, 1.5 times more carbohydrates and 1.4 times more proteins than $T$. testudinum from our study site in St. Joe Bay (Prado et al. unpubl. data). In other herbivores, such as the amphipod Ampithoe longimana, spatial variability accounted for greater preference for plants from inshore versus offshore populations, which had consistently lower contents of secondary metabolites (Taylor et al. 2003).

The potential implications of consumer preferences for Syringodium filiforme may involve local overgrazing of this species, which is often scarce compared to Halodule wrightii and Thalassia testudinum, particularly in areas where parrotfish are abundant. The emerald parrotfish Nicholsina usta is the most abundant herbivorous fish in the Caribbean seagrass meadows of Venezuela, where it feeds predominantly on seagrass leaves (Allen et al. 2006), but previous records (Fodrie et al. 2010) indicate that this species was formerly uncommon in the northern gulf region. However, recent studies in northern Gulf of Mexico meadows have shown a 22 -fold increase in the abundance of $N$. usta along with a regional increase of $>3^{\circ} \mathrm{C}$ in water temperature (Fodrie et al. 2010). During our experiments, this species consumed nearly 5 times more seagrass than the main seagrass grazer in the northern Gulf of Mexico, the sea urchin Lytechinus variegatus (Heck \& Valentine 1995), and 11 and
36 times, respectively, more seagrass than the omnivorous filefish and pinfish; similar patterns of differences were also observed when consumers were exposed to reconstituted diets. Additionally, other species of parrotfish such as the bucktooth parrotfish Sparisoma radians and the bluelip parrotfish Cryptotomus roseus, which are also important seagrass herbivores in southern Florida (Kirsch et al. 2002) and the Caribbean (Weinstein \& Heck 1979), are becoming more common in northern bays of the Florida coastline (Fodrie et al. 2010) and could influence the local abundance of seagrass species. However, further research is necessary to elucidate the possible effects of food preferences on seagrass meadows. First, the low N:P and C:P ratios of parrotfish (and sea urchins) compared to seagrass diets suggests that consumers may be P limited (see Hood et al. 2005) and that other P-richer resources could be positively selected over seagrass leaves when available. Also, importantly, there is evidence that both parrotfish and sea urchins prefer epiphyte-coated T. testudinum over naked leaves (review by Watts et al. 2001). Hence, differences in biomass load and/or epiphytic assemblages among species may have important consequences for trophic interactions. Finally, the higher structural complexity of Thalassia spp. beds offers a much better habitat for small or young individuals, which are comparatively more abundant than within beds of Halodule spp. and Syringodium spp. (Beddingfield \& McClintock 2000) and might not abandon a secure shelter during daily foraging activity.

To conclude, our results show that northern Gulf of Mexico macrograzers-fish and sea urchins-select seagrass species primarily based on nutritional characteristics (possibly through effective gustation and/or olfaction of chemical cues) even when differences among dietary components are relatively low. Although plant structural features (possibly plant biteability and/or visually detected aspects such as shape and size) also influenced daily consumption rates, they did not completely modify food preferences. In contrast, the omnivore species investigated may require greater nutritional stimuli to noticeably impact seagrass beds (Heck et al. 2000, 2006), but they are able to discriminate among seagrass species based on their structural characteristics. Our results also suggest that seagrass systems with diverse herbivore and omnivorous guilds may be more resilient to disturbance regimes (reviewed by Folke et al. 2004) due to the capacity of consumers to sense nutritional characteristics within a wide spectrum of variability and the influence of nutrients in shaping the relative abundance of seagrass species. Further research is, however, necessary to assess the generality of the observed patterns in other species and regions. 
Acknowledgements. P. Prado was supported by a postdoctoral scholarship from the Ramón Areces Foundation, and partial support of this work was provided by NOAA MARFIN and NOAA Northern Gulf Institute grants to K.H. We are very grateful to J. Fodrie for help in collecting fish and sea urchins for our experiments, and to Caitlain Bovery for assistance with leaf toughness measurements. We thank the Tech Support team at the Dauphin Island Sea Lab for helping us maintain the appropriate physicochemical conditions in experimental tanks, and Professor S.A. Watts for advice and for use of his laboratory for the determination of lipid and carbohydrate contents of seagrasses.

\section{LITERATURE CITED}

Allen T, Jiménez M, Villafranca S (2006) Trophic structure and categories of fish associated with Thalassia testudinum meadows (Hydrocharitales, Hydrocharitaceae) in Golfo de Cariaco, Estado de Sucre, Venezuela. Invest Mar 34:125-136

Ang JP, Newman LJ (1998) Warning colouration in pseudocerotid flatworms (Platyhelminthes, Polycladida). A preliminary study. Hydrobiologia 383:29-33

> Armitage AR, Fourqurean JW (2006) The short-term influence of herbivory near patch reefs varies between seagrass species. J Exp Mar Biol Ecol 339:65-74

Beddingfield SD, McClintock JB (1998) Differential survivorship, reproduction, growth and nutrient allocation in the regular echinoid Lytechinus variegatus (Lamarck) fed natural diets. J Exp Mar Biol Ecol 226:195-215

Beddingfield SD, McClintock JB (2000) Demographic characteristics of Lytechinus variegatus (Echinoidea: Echinodermata) from three habitats in a North Florida Bay, Gulf of Mexico. PSZNI: Mar Ecol 21:17-40

Carr WES, Netherton JC III, Gleeson RA, Derby CD (1996) Stimulants of feeding behavior in fish: analyses of tissues of diverse marine organisms. Biol Bull 190:149-160

> Checkley DM Jr (1982) Selective feeding by Atlantic herring (Clupea harengus) larvae on zooplankton in natural assemblages. Mar Ecol Prog Ser 9:245-253

Chiao CC, Hanlon RT (2001) Cuttlefish camouflage: visual perception of size, contrast and number of white squares on artificial checkerboard substrata initiates disruptive coloration. J Exp Biol 204:2219-2125

Conover WJ (1980) Practical nonparametric statistics. John Wiley and Sons, New York, NY

> Conover WJ, Iman RL (1981) Rank transformations as a bridge between parametric and nonparametric statistics. Am Stat 35:124-129

Cronin G, Lodge DM, Hay ME, Miller M and others (2002) Crayfish feeding preferences for freshwater macrophytes: the influence of plant structure and chemistry. J Crustac Biol 22:708-718

> Cruz-Rivera E, Hay ME (2000) Can quantity replace quality? Food choice, compensatory feeding, and fitness of marine mesograzers. Ecology 81:201-219

Danell K, Utsi PM, Thomas Palo R, Eriksson O (1994) Food plant selection by reindeer during winter in relation to plant quality. Ecography 17:153-158

Dubois M, Gilles KA, Hamilton JK, Reber PA, Smith F (1956) Colorimetric method for determination of sugars and related substances. Anal Chem 28:350-356

Duffy JE, Hay ME (1991) Food and shelter as determinants of food choice by an herbivorous marine amphipod. Ecology 72:1286-1298

Duffy JE, Hay ME (1994) Herbivore resistance to seaweed chemical defense: the roles of mobility and predation risk. Ecology 75:1304-1319

Dusenbery DB (1992) Sensory ecology. How organisms acquire and respond to information. Freeman, New York, NY

Farmanfarmaian A, Phillips JH (1962) Digestion, storage, and translocation of nutrients in the purple sea urchin (Strongylocentrotus purpuratus). Biol Bull 123:105-120

Fernández-Diaz C, Pascual M, Yúfera M (1994) Feeding behaviour and prey size selection of gilthead seabream, Sparus aurata, larvae fed on inert and live food. Mar Biol 118:323-328

Fodrie FJ, Heck KL Jr, Powers SP, Graham WM, Robinson KL (2010) Climate-related, decadal-scale assemblage changes of seagrass-associated fishes in the northern Gulf of Mexico. Glob Change Biol 16:48-59

Folch J, Lees M, Sloane Stanley GH (1957) A simple method for the isolation and purification of total lipids from animal tissues. J Biol Chem 226:497-509

Folke C, Carpenter S, Walker B, Scheffer M, Elmqvist T, Gunderson L, Holling CS (2004) Regime shifts, resilience, and biodiversity in ecosystem management. Annu Rev Ecol Evol Syst 35:557-581

> Goecker ME, Heck KL, Valentine JF (2005) Effects of nitrogen concentrations in turtlegrass Thalassia testudinum on consumption by the bucktooth parrotfish Sparisoma radians. Mar Ecol Prog Ser 286:239-248

> Hambright KD (1991) Experimental analysis of prey selection by largemouth bass: role of predator mouth width and prey body depth. Trans Am Fish Soc 120:500-508

- Hay ME, Fenical W (1988) Marine plant-herbivore interactions: the ecology of chemical defense. Annu Rev Ecol Syst 19:111-145

Heck KL, Valentine JF (1995) Sea urchin herbivory: evidence for long lasting effects in subtropical seagrass meadows. J Exp Mar Biol Ecol 189:205-217

Heck KL, Pennock JR, Valentine JF, Coen LD, Sklenar SA (2000) Effects of nutrient enrichment and small predator density on seagrass ecosystems: an experimental assessment. Limnol Oceanogr 45:1041-1057

Heck KL Jr, Valentine JF, Pennock JR, Chaplin G, Spitzer PM (2006) Effects of nutrient enrichment and grazing on shoalgrass Halodule wrightii and its epiphytes: results of a field experiment. Mar Ecol Prog Ser 326:145-156

Hood JM, Vanni MJ, Flecker AS (2005) Nutrient recycling by two phosphorus-rich grazing catfish: the potential for phosphorus-limitation of fish growth. Oecologia 146: 247-257

> Hyslop EJ (1980) Stomach contents analysis - a review of methods and their application. J Fish Biol 17:411-429

Jensen KR (1997) Evolution of the Sacoglossa (Mollusca, Opisthobranchia) and the ecological associations with their food plants. Evol Ecol 11:301-335

Kasumyan AO, Døving KB (2003) Taste preferences in fishes. Fish Fish 4:289-347

Kendall MG (1955) Rank correlation methods, 2nd edn. Griffin and Co., London

- Kirsch KD, Valentine JF, Heck KL Jr (2002) Parrotfish grazing on turtlegrass Thalassia testudinum: evidence for the importance of seagrass consumption in food web dynamics of the Florida Keys National Marine Sanctuary. Mar Ecol Prog Ser 227:71-85

Klinger TS (1982) Feeding rates of Lytechinus variegatus Lamark (Echinodermata: Echinoidea) on differing physiognomies of an artificial food on a uniform composition. In: Lawrence JM (ed) Echinoderms. Proc Int Conf, Tampa Bay. AA Balkema, Rotterdam, p 29-32

Klumpp DW, Nichols PD (1983) Nutrition of the southern sea 
garfish Hyporhamphus melanochir: gut passage rate and daily consumption of two food types and assimilation of seagrass components. Mar Ecol Prog Ser 12:207-216

Liang XF, Liu JK, Huang BY (1998) The role of sense organs in the feeding behaviour of Chinese perch. J Fish Biol 52: 1058-1067

Lima SL (2002) Putting predators back into behavioral predator-prey interactions. Trends Ecol Evol 17:70-75

Lobel PS, Ogden JC (1981) Foraging by the herbivorous parrotfish Sparisoma radians. Mar Biol 64:173-183

McMillan C (1984) The condensed tannins (proanthocyanidins) in seagrasses. Aquat Bot 20:351-357

Montgomery WL, Gerking SD (1980) Marine macroalgae as foods for fishes: an evaluation of potential food quality. Environ Biol Fishes 5:143-153

Moore P, Crimaldi J (2004) Odor landscapes and animal behavior: tracking odor plumes in different physical worlds. J Mar Sci 49:55-64

New JG (2002) Multimodal integration in the feeding behaviors of predatory teleost fishes. Brain Behav Evol 59: $177-189$

Ojeda P, Caceres CW (1995) Digestive mechanisms in Aplodactylus punctatus (Valenciennes): a temperate marine herbivorous fish. Mar Ecol Prog Ser 118:37-42

Parrish JK (1991) Do predators 'shape' fish schools: interactions between predators and their schooling prey. Neth J Zool 42:358-370

Paul VJ, Hay ME (1986) Seaweed susceptibility to herbivory: chemical and morphological correlates. Mar Ecol Prog Ser 33:255-264

Prado P, Romero J, Alcoverro T (2010) Nutrient status, plant availability and seasonal forcing mediate fish herbivory behavior in temperate seagrass beds. Mar Ecol Prog Ser 409:229-239

Senft RL, Coughenour MB, Bailey DW, Rittenhouse LR, Sala OE, Swift DM (1987) Large herbivore foraging and ecological hierarchies. BioScience 37:789-799

Steele L, Valentine JF (2010) Phenolic content of two subtropical seagrasses affects feeding behavior of mesograzers but not macrograzers. In: Benthic ecology meeting 2010, Wilmington, NC, USA. Univ. N. Carolina, Wilmington, p 185 (abstract)

Steneck RS, Sala E (2005) Large marine carnivores: trophic cascades and top-down controls in coastal ecosystems past and present. In: Ray J, Redford K, Steneck R, Berger J (eds) Large carnivores and the conservation of biodiver-

Editorial responsibility: Catriona Hurd, Dunedin, New Zealand sity. Island Press, Washington, DC, p 110-137

Steneck RS, Watling L (1982) Feeding capabilities and limitation of herbivorous molluscs: a functional group approach. Mar Biol 68:299-319

Stephens DW, Krebs JR (1987) Foraging theory. Princeton University Press, Princeton, NJ

Targett TE, Targett NM (1990) Energetics of food selection by the herbivorous parrotfish Sparisoma radians: roles of assimilation efficiency, gut evacuation rate, and algal secondary metabolites. Mar Ecol Prog Ser 66:13-21

Taylor RB, Sotka E, Hay ME (2002) Tissue-specific induction of herbivore resistance: seaweed response to amphipod grazing. Oecologia 132:68-76

> Taylor RB, Lindquist N, Kubanek J, Hay ME (2003) Intraspecific variation in palatability and defensive chemistry of brown seaweeds: effects on herbivore fitness. Oecologia 136:412-423

> Tribble GV (1981) Reef-basel herbivores and the distribution of two seagrasses (Syringodium filiforme and Thalassia testudinum) in the San Blas Islands (western Caribbean). Mar Biol 65:277-281

Valentine JF, Duffy JE (2006) The central role of grazing in seagrass ecology. In: Larkum WD, Orth RJ, Duarte CM (eds) Seagrasses: biology, ecology, and conservation. Springer, Dordrecht, p 463-501

Valentine JF, Heck KL (2001) The role of leaf nitrogen content in determining turtlegrass (Thalassia testudinum) grazing by a generalized herbivore in the northeastern Gulf of Mexico. J Exp Mar Biol Ecol 258:65-86

> Vergés A, Becerro MA, Alcoverro T, Romero J (2007) Variation in multiple traits of vegetative and reproductive seagrass tissues influences plant-herbivore interactions. Oecologia 151:675-686

Watts SA, McClintock JB, Lawrence JM (2001) The ecology of Lytechinus variegatus. In: Lawrence JM (ed) Edible sea urchins: biology and ecology. Elsevier, Amsterdam, p 375-393

> Weinstein MP, Heck KL (1979) Ichthyofauna of seagrass meadows along the Caribbean coast of Panama and in the Gulf of Mexico: composition, structure and community ecology. Mar Biol 50:97-107

Weissburg MJ, Fenner MC, Pisut DP, Smee DL (2002) Ecological consequences of chemically mediated prey perception. J Chem Ecol 28:1953-1970

Zimmer RK, Butman CA (2000) Chemical signaling processes in the marine environment. Biol Bull 198:168-187

Submitted: July 5, 2010; Accepted: February 6, 2011

Proofs received from author(s): April 22, 2011 